\title{
Factors Associated With Toxoplasma gondii lgG and IgM Antibodies, and Placental Histopathological Changes Among Women With Spontaneous Abortion in Mwanza City, Tanzania
}

\author{
Illuminata Machumi, ${ }^{a}$ Mariam M Mirambo, ${ }^{b}$ Deodatus Ruganuza, ${ }^{c}$ Peter Rambau, ${ }^{\mathrm{d}}$ Anthony N Massinde, ${ }^{a}$ \\ Albert Kihunrwa, ${ }^{a}$ Stephen E Mshana, ${ }^{b}$ Domenica Morona ${ }^{c}$ \\ a Department of Obstetrics and Gynaecology, Weill Bugando School of Medicine, Mwanza, Tanzania; ${ }^{b}$ Department of Microbiology and Immunology, Weill Bugando \\ School of Medicine, Mwanza, Tanzania; ${ }^{C}$ Department of Medical Parasitology and Entomology, Weill Bugando School of Medicine, Mwanza, Tanzania; ${ }^{\mathrm{d}}$ Department \\ of Pathology, Weill Bugando School of Medicine, Mwanza, Tanzania. \\ Correspondence to Domenica Morona (dmorona@gmail.com)
}

\begin{abstract}
Background: Toxoplasma gondii infection in early pregnancy has been associated with significant adverse pregnancy outcomes. Despite being common in the city of Mwanza, its association with spontaneous abortion has never been studied. Here, we report the $\lg G$ and $\lg M$ seropositivity and histopathological changes of toxoplasmosis among women with spontaneous abortion.

Methods: A total of 260 women with spontaneous abortion were enrolled between November 2015 and April 2016 from 4 hospitals in Mwanza city. Specific T. gondii lgG and IgM antibodies were detected from sera by indirect enzyme-linked immunosorbent assay (ELISA) while the conceptus tissues were stained with haematoxylin and eosin to demonstrate histopathological changes. Data were analysed by using Stata version 13.

Results: The mean age of the enrolled women was $26 \pm 5.9$ years. The seropositivity of $\lg G$ and $\lg M$ antibodies were $144 / 260$ (55.4\%; $95 \%$ confidence interval [Cl], 49-61) and 6/260 (2.3\%; 95\% Cl, 3-8), respectively. IgG seropositivity was significantly high among women in the first trimester (59.1\% vs.43.5\%; $P=.03$ ). Only low gestation age (odds ratio [OR] $1.11 ; 95 \% \mathrm{Cl}, 1.02-1.20 ; P=.02)$ and keeping a cat (OR 11.80;95\% Cl, 1.32-10.5; $P=.03$ ) independently predicted $\lg G$ and $\lg M$ seropositivity, respectively. Presence of inflammation (OR 1.95; $95 \% \mathrm{Cl}, 1.05-3.64 ; P=.03$ ), calcification (OR 3.28; 95\% Cl, 1.01-10.63; $P=.04$ ), necrosis (OR 2.86; 95\% Cl, 1.39-5.89; $P=.04$ ), and lymphocyte infiltrations (OR 2.24; 95\% Cl, 1.17-4.24; $P=.01$ ) were significantly associated with $T$. gondii lgG seropositivity.

Conclusions: Almost half of women with spontaneous abortion in the city of Mwanza have specific $T$. gondii lgG antibodies. Placental histopathological changes suggestive of toxoplasmosis were significantly found among lgG seropositive women. This calls for the need to screen these women during antenatal visits in order to institute appropriate measures, such as treatment and counselling, to prevent complications associated $T$. gondii infection.
\end{abstract}

\section{BACKGROUND}

$\mathbf{T}$ oxoplasmosis is a common infection caused by a coccidian intracellular protozoan parasite, Toxoplasma gondii, which occurs in domestic animals and humans throughout the world. It is a public health concern by reason of its neurological manifestations among human immunodeficiency virus/acquired immunodeficiency syndrome (HIV/AIDS) patients and the potential association with adverse pregnancy outcomes. ${ }^{1-4}$ The infection is mainly acquired through ingestion of undercooked or raw meat containing viable cysts, ingestion of food and water contaminated with oocysts shed by cats, or congenitally during pregnancy. ${ }^{5-7}$ The course of the primary infection is often subclinical, with a majority of the infected individuals remaining asymptomatic; few patients may present mild symptoms. ${ }^{8,9}$ Primary infections during pregnancy are often asymptomatic but may result into foetal complications like spontaneous abortions, stillbirths, severe congenital 
malformations, and central nervous system symptoms in apparently normal infants. ${ }^{10-13}$ There is a geographical variation of the epidemiology of T. gondii infection. One-third of the world's population is estimated to be infected with T. gondii. ${ }^{14,15}$ About $0.01 \%$ to $0.1 \%$ of infants in developed countries are affected by congenital toxoplasmosis. ${ }^{16}$ Primary infection during the third trimester carries a higher risk of congenital infection than infection in the first and second trimesters. ${ }^{16-18}$ However, severe foetal sequels occur when the disease is acquired in the first trimester. ${ }^{8,19}$ Though data from African countries are still scarce, a few studies carried out in Tanzania have documented the magnitude of toxoplasmosis, ${ }^{20-23}$ however, none of these studies focused on women with spontaneous abortion. A high prevalence of toxoplasmosis among women with spontaneous abortions has been reported in Egypt and Mexico. ${ }^{24,25}$ Given the fact the $T$. gondii seropositivity among pregnant women is high in $\mathrm{Mwanza}^{20}$ there is a paramount need to investigate its association with poor pregnancy outcomes. The current study was undertaken in Mwanza to investigate the role of $T$. gondii infection as a potential cause of spontaneous abortion. The data collected may inform policy makers and prompt them to consider the need for a policy of screening and treatment of this infection during pregnancy to reduce possible associated complications.

\section{MATERIALS AND METHODS}

\section{Study Design and Study Area}

A cross-sectional hospital-based study was conducted between November 2015 and April 2016 involving 4 health facilities in the city of Mwanza, Tanzania. The 4 facilities included the Bugando Medical Centre (BMC), Sekou Toure regional hospital, Nyamagana district hospital, and Buzuruga health centre. These sites were purposively selected because they serve a large population of the city and provide obstetrics and gynaecological services for women with spontaneous abortion.

\section{Study Population and Inclusion and Exclusion Criteria}

The study included all women diagnosed with spontaneous abortion in their first and second trimester of the pregnancy attending obstetrics and gynaecology clinics and emergency departments at the 4 selected sites. Women who were unsure about the dates of their last normal menstrual period and those in critical condition were excluded from the study.

\section{Sample Size Estimation and Sampling Techniques}

The sample size was estimated by the Kish Leslie formula, ${ }^{26}$ using the prevalence of $12.8 \%$ from Kistiah et al. ${ }^{27}$ The minimum sample size calculated was 174, however a total of 260 women were enrolled. A serial sampling technique was used to enrol participants until the desired sample size was reached.

\section{Data Collection}

Sociodemographic and medical/obstetric information was collected by a direct assessment of the study participants and pre-tested structured questionnaires.

\section{Sample Collection Procedure and Laboratory Investigations}

During the collection of tissue samples, a checklist was provided to exclude observable signs of induced abortion, such as lacerations, cervical bruises, and foreign bodies during evacuation. A small sample of conceptus was collected and placed into $10 \%$ neutral buffered formalin for fixation. The tissues were subsequently processed and stained by haematoxylin and eosin as previously described. ${ }^{28}$ Slides were read by an experienced pathologist to detect the presence of necrosis, calcifications, plasma cells, and different forms of inflammation and to identify tachyzoites and bradyzoites.

For serological diagnosis, about $5 \mathrm{~mL}$ of venous blood was collected aseptically using plain vacutainer tubes (Becton, Dickinson and Company, Nairobi, Kenya). The samples were then taken to the Catholic University of Health and Allied Sciences (CUHAS) multipurpose laboratory where the serum was separated by centrifugation at 3,000 rpm for 5 minutes. The sera were kept at $-40^{\circ} \mathrm{C}$ until processing. The detection of specific Toxoplasma IgM and IgG antibodies was done by commercial indirect enzyme-linked immunosorbent assay (ELISA) (PishtazTeb Diagno-stics, Teheran, Iran). The IgM ELISA assay used IgM capture principle. All procedures followed manufacturer instructions. A standard curve for IgG antibody detection was obtained by calibrating the standards 1 to 5 with concentration of $0,10,50,100$, and $200 \mathrm{IU} / \mathrm{mL}$ using ChemWell 2910 Automated EIA (Awareness Technology, Inc., Palm City, Florida, USA) as per manufacturer's instructions.

\section{Data Analysis}

Data were entered into Microsoft Office Excel 2013. Coding and analysis were carried out using Stata version 13 (StataCorp, College Station, Texas, USA). Continuous variables, such as age, gestation age, gravidity, and antibody titres were summarized as median with interquartile range (IQR) or means with standard deviation. Categorical variables such as marital status, residence, education level, occupation, history of miscarriage, history of stillbirths, HIV status, keeping a cat, drinking unboiled water, or consuming pork, chicken, mutton, lamb, or beef were summarized as proportions. For the histopathological results, data were analysed using the Pearson's Chi-square test to observe the statistical differences of proportions in the various groups. In addition, the Wilcoxon Ranksum (Mann Whitney) test was used to compare differences on the medians between the groups. Univariate and multivariate logistic regression models were used to determine the predictors of $T$. gondii infection. Predictors with $P$-value of less than 0.2 were 
subjected into multivariate logistic regression analysis and their ORs and $95 \%$ CIs were noted. Predictors with $P$ values of less than 0.05 were considered statistically significant.

Ethics approval and consent to participate

Ethical approval was obtained from the joint CUHAS/BMC research ethics and review committee with ethical clearance number CREC/103/2015. Written informed consent was obtained from each participant prior to enrolment in the study. For participants aged below 18 years, consent was given by the parents/guardians who accompanied them.

\section{RESULTS}

\section{Sociodemographic Characteristics of the 260 Women Enrolled in the Study}

The mean age of enrolled women was $26 \pm 5.9$ years. The majority $(198,76.2 \%)$ were in the first trimester, and $160(61.5 \%)$ resided in rural areas. A total of $147(56.5 \%)$, $86(33.1 \%)$, and $27(10.4 \%)$ had either no formal/primary, secondary, or tertiary education, respectively. The median gestation age of the enrolled women was 11 (IQR 9-13) weeks. A total of $114(43.8 \%)$ of the enrolled women were housewives, while $58(19.2 \%)$ and 88 (33.8\%) were peasants or employed, respectively. The majority of women $185(71.1 \%)$ were either primipara-a woman who is giving birth for the first time-or had at least 1 previous birth, as shown in Table 1.

\section{Seropositivity of Specific T. gondii Antibodies Among Women with Spontaneous Abortion}

The seropositivity of IgG antibodies was 144/260 (55.4\%; 95\% CI, 49-61). Of the 198 women who were in the first trimester, $117(59.09 \%)$ were IgG seropositive compared to only $27 / 62(43.5 \%)$ of those in second trimester $(P=.03)$. Regarding IgM seropositivity, the seropositivity was $6 / 260$ $(2.3 \% ; 95 \%$ CI, 3-8).

\section{Factors Associated with Specific T. gondii Antibodies Among Women with Spontaneous Abortion}

The median gestation age of IgG seropositive women was significantly lower than the median gestation age of IgG seronegative women ( 11 IQR 9-13 vs. 12 IQR 10-14; $P=.02$ ). On univariate logistic regression analysis, the decrease in gestation age (OR 1.09; 95\% CI, 1.10-1.19; $P<.03)$ was significantly associated with IgG seropositivity (Figure 1). There was no significant difference between the mean age of IgG seropositive women and that of IgG seronegative women (26 \pm 5.9 vs. $25 \pm 5.8 ; P=.17$ ).

Out of 4 participants with HIV-positive status, 3 (75\%) were IgG seropositive compared to 105 (55.3\%) and $36(54.6 \%)$ of those with HIV-negative status and those with unknown status, respectively $(P>.05)$. Other factors

\begin{tabular}{lc}
\hline TABLE 1. Sociodemographic Characteristics of the \\
260 Women With Spontaneous Abortion Enrolled in the \\
Study \\
\hline Characteristics & $\mathbf{n}(\%)$ \\
\hline Age* & $26 \pm 5.9$ \\
Gestation age* & 11 (IQR 9-13) \\
First trimester & $198(76.2)$ \\
Second trimester & $62(23.8)$ \\
Education & \\
No formal/primary & $147(56.5)$ \\
Secondary & $86(33.1)$ \\
Tertiary & $27(10.4)$ \\
Residence & \\
Rural & $160(61.5)$ \\
Urban & $100(38.5)$ \\
Occupation & \\
Housewife & $114(43.8)$ \\
Peasant & $58(19.2)$ \\
Employed & $88(33.8)$ \\
Parity & \\
Nullipara/0 children & $75(28.9)$ \\
$\geq 1$ children & $185(71.1)$ \\
\hline * Mean age and median gestation age of the study participants. \\
Abbreviation: IQR, interquartile range.
\end{tabular}

investigated, such as residing in urban areas, history of previous miscarriage, history of stillbirth, drinking unboiled water, and keeping a cat were found to have a nonstatistical increased risk of being IgG seropositive, as shown in Table 2. Only low gestation age (OR 1.11; 95\% CI, $1.02-1.20 ; P=.02$ ) was found to predict IgG seropositivity on multivariate logistic regression analysis (Table 2 ).

Regarding the factors associated with IgM seropositivity, out of 169 women reported to keep cats, 5 (5.7\%) were found to be IgM seropositive compared to only l out of 170 who reported not to keep cats $(P=.037)$. Other factors such as history of stillbirth, drinking unboiled water, and not eating mutton or chicken were found to have a nonstatistical increased risk of IgM seropositivity, as shown in Table 3. Only keeping cat (OR 11.8; 95\%CI, 1.32-10.5; $P=.03$ ) was found to predict IgM seropositivity on multivariate logistic regression analysis (Table 3 ). 


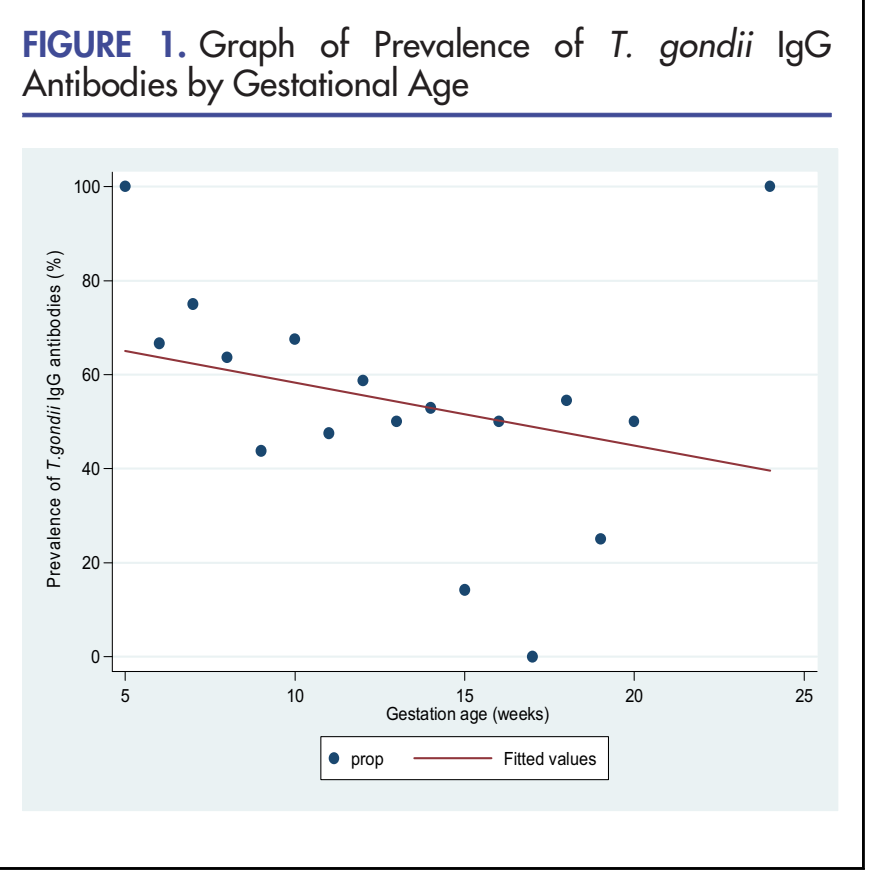
Histopathological Changes of Conceptus Products and
T. gondii lgG Seropositivity

Conceptus products were obtained from 171 women. The histopathological changes examined included presence/ absence of inflammation, including inflammatory cells such as macrophages, neutrophils, lymphocytes, and eosinophils, calcification, necrosis, and presence of tachyzoites and bradyzoites (Figures 2 and 3 ).

Presence of inflammation (OR 1.95; 95\% CI, 1.05-3.64; $P=.04$ ), calcification (OR 3.28; 95\% CI, 1.01-10.63; $P=.05$ ), necrosis (OR 2.86; 95\% CI, 1.39-5.89; $P=.01$ ), and lymphocytes (OR 2.24; 95\% CI, 1.17-4.24; $P=.01$ ) were significantly associated with specific $T$. gondii IgG seropositivity (Table 4). The presence of histopathological changes had a nonstatistical association with increased IgG median titres.

\section{DISCUSSION}

T. gondii infections have been implicated in poor pregnancy outcomes and as a common cause of cerebral toxoplasmosis among patients infected with HIV. For the first time in Tanzania, we document a high seropositivity of specific T. gondii IgG antibodies among women with spontaneous abortion. Our findings are comparable to those reported elsewhere. ${ }^{24,29}$ In comparison to previous studies in Sudan and Tehran, ${ }^{30,31}$ the reported prevalence in the current study is indeed high. The difference could be attributed to a number of factors, such as geographical variation and climatic conditions, which have been found to influence toxoplasmosis worldwide. $^{32}$ Moist and warm temperatures have been reported to enhance the sporulation of $T$. gondii oocysts. Generally, Mwanza's climate is warm with the temperature peaking around the third quarter of the year, which may explain high transmission rates. In addition, the prevalence reported in this study is significantly higher than what was reported in a previous study among pregnant women in the same setting and in an earlier report of data collected in the general population. ${ }^{20,22}$ The difference could be explained by the difference in study populations emphasizing the possible role $T$. gondii in causing spontaneous abortion.

The IgG seropositivity in this study was found to increase with an increase in maternal age, this confirms what was reported earlier. ${ }^{20,33}$ In addition, a lower gestation age was significantly associated with IgG seropositivity in this study. This corroborates the fact that most of the adverse T. gondii infection outcomes tend to occur during early pregnancy. ${ }^{12}$ Furthermore, women with a previous history of miscarriage and a history of stillbirth had increased odds of being $\operatorname{IgG}$ seropositivity, which was also reported previously. ${ }^{31,34}$

T. gondii IgM seropositivity in the current study is comparable to the previous study in Tehran, Iran, which reported a seropositivity of $2.7 \% .{ }^{31}$ In contrast, the reported IgM seropositivity in the current study is low compared to previous studies in Sudan and Egypt. ${ }^{24,29,30}$ In comparison with a previous study conducted in the same settings ${ }^{20}$ among pregnant women with full-term delivery, the IgM seropositivity in the current study is indeed high. The presence of specific T. gondii IgM antibodies among these women may explain the primary infection, which is often associated with poor foetal outcome when acquired in the first 12 weeks of the pregnancy. However, in many cases, specific T. gondii IgM antibodies tend to persist longer after primary infection. Therefore, in these cases, an IgG avidity test is recommended to exclude the possibility of previous infections. ${ }^{36}$ Keeping cats was significantly associated with IgM seropositivity, which is consistent with other studies that reported the increased risk of T. gondii infections among pregnant women handling cats. ${ }^{33,37}$

This study observed that the odds of being Ig G seropositive were significantly high among women with placental histopathological changes. It has been previously suggested that the mechanism by which T. gondii induce abortion is through a chain of placental immunological reactions. ${ }^{24}$ Animal model studies suggest that abortion can be induced by pathological changes, even without parasite replication in placental tissues. ${ }^{38}$ Inflammation was significantly associated with IgG seropositivity in the current study. This finding has also been reported in a previous study with a positive correlation between intensity of inflammation and poor foetal outcome. ${ }^{39}$ Despite the fact that placental inflammation is non-specific and that the majority of incidents are of unknown origin, a positive correlation with IgG seropositivity suggests that $T$. gondii infection might have played a key role in this context. ${ }^{40,41}$ Highly sophisticated techniques are recommended to confirm the presence of parasites in placental tissues, since 
TABLE 2. Univariate and Multivariate Logistic Regression Analysis of Factors Associated With $T$. gondii lgG Seropositivity Among 260 Women With Spontaneous Abortion in Mwanza City

\begin{tabular}{|c|c|c|c|c|c|}
\hline Characteristics (n) & $\begin{array}{l}\text { IgG Seropositivity } \\
\text { n (\%) }\end{array}$ & Univariate OR $(95 \% \mathrm{Cl})$ & P-Value & Multivariate OR $(95 \% \mathrm{Cl})$ & P-Value \\
\hline $\mathrm{Age}^{*}$ & $26 \pm 5.9$ & $1.02(0.98-1.07)$ & .188 & $1.03(0.98-1.07)$ & .18 \\
\hline Gestation age* & 11 (IQR 9-13) & $1.09(1.01-1.17)$ & .028 & $1.11(1.02-1.2)$ & .02 \\
\hline Gravidity* & 3 (IQR 1-4) & $1.06(0.92-1.22)$ & .397 & & \\
\hline \multicolumn{6}{|l|}{ Residence } \\
\hline Rural (160) & $84(52.5 \%)$ & 1 & & & \\
\hline Urban (100) & $60(60 \%)$ & $1.35(0.81-2.25)$ & .237 & & \\
\hline \multicolumn{6}{|l|}{ Education } \\
\hline No formal/primary (147) & $82(55.8 \%)$ & 1 & & & \\
\hline Secondary (86) & 46 (53.5\%) & $1.00(0.53-1.55)$ & .734 & & \\
\hline Tertiary (27) & $16(59.2 \%)$ & $1.15(0.50-2.65)$ & .738 & & \\
\hline \multicolumn{6}{|l|}{ Occupation } \\
\hline Housewife (1 14) & $57(50 \%)$ & 1 & & & \\
\hline Peasant (58) & $37(63.8 \%)$ & $1.76(0.92-3.37)$ & .087 & $1.54(0.81-2.92)$ & .18 \\
\hline Employed (88) & $50(56.4 \%)$ & $1.32(0.75-2.30)$ & .336 & & \\
\hline Marital status & $19(50 \%)$ & 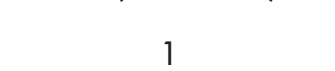 & & & \\
\hline Married (222) & $125(56.3 \%)$ & $1.23(0.64-2.57)$ & .471 & & \\
\hline \multicolumn{6}{|l|}{$\begin{array}{l}\text { Previous miscarriage } \\
\text { No }(221)\end{array}$} \\
\hline Yes (39) & $25(64.1 \%)$ & $1.53(0.75-3.09)$ & .237 & & \\
\hline \multicolumn{6}{|l|}{ HIV status } \\
\hline Unknown (66) & $36(54.6 \%)$ & $1.00(0.55-1.77)$ & .920 & & \\
\hline Positive (4) & $3(75 \%)$ & $2.43(0.24-23.77)$ & .446 & & \\
\hline \multicolumn{6}{|l|}{ History of stillbirth } \\
\hline No (225) & $121(53.8 \%)$ & 1 & & & \\
\hline Yes (35) & $23(65.7 \%)$ & $1.65(0.78-3.47)$ & .189 & $1.51(0.67-3.37)$ & .31 \\
\hline \multicolumn{6}{|l|}{ Keeping a cat } \\
\hline No $(170)$ & $87(51.2 \%)$ & 1 & & & \\
\hline Yes $(90)$ & $57(63.3 \%)$ & $1.65(0.97-2.78)$ & .062 & $1.29(0.69-2.39)$ & .425 \\
\hline \multicolumn{6}{|l|}{$\begin{array}{l}\text { Unboiled water } \\
\text { Yes (91) }\end{array}$} \\
\hline No (169) & 88 (52.1\%) & $1.47(0.87-2.47)$ & .144 & & \\
\hline Beef & $25(55.7 \%)$ & 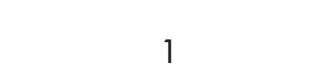 & & & \\
\hline Yes (215) & $119(55.4 \%)$ & $0.99(0.51-1.19)$ & .980 & & \\
\hline \multicolumn{6}{|l|}{ Chicken } \\
\hline No (84) & $51(60.7 \%)$ & 1 & & & \\
\hline \multicolumn{6}{|c|}{$0.72(0.42-1.23)$} \\
\hline No (142) & $85(59.7 \%)$ & 1 & & & .235 \\
\hline Yes (1 18) & $59(50 \%)$ & $0.67(0.41-1.09)$ & .112 & $0.72(0.43-1.23)$ & \\
\hline \multirow{3}{*}{$\begin{array}{l}\text { Pork } \\
\text { No (200) } \\
\text { Yes (60) } \\
\text { Lamb } \\
\text { No (215) } \\
\text { Yes (45) }\end{array}$} & $\begin{array}{c}105\left(\begin{array}{l}52.5 \%) \\
39(65 \%)\end{array}\right.\end{array}$ & $1.68(0.92-3.05)$ & .08 & $1.81(0.95-3.44)$ & .06 \\
\hline & $120(55.8 \%)$ & 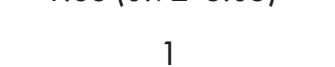 & & & \\
\hline & $24(55.3 \%)$ & $0.90(0.47-1.72)$ & .761 & & \\
\hline
\end{tabular}


TABLE 3. Univariate and Multivariate Logistic Regression Analysis of Factors Associated With T. gondii lgM Seropositivity Among 260 Women With Spontaneous Abortion in Mwanza City

\begin{tabular}{|c|c|c|c|c|c|}
\hline Characteristics (n) & $\begin{array}{c}\text { IgG Seropositivity } \\
\text { n (\%) }\end{array}$ & Univariate OR $(95 \% \mathrm{Cl})$ & P-Value & Multivariate OR $(95 \% \mathrm{Cl})$ & P-Value \\
\hline $\mathrm{Age}^{\star}$ & $22 \pm 3.7$ & $0.85(0.72-1.02)$ & .083 & $0.88(0.68-1.13)$ & .319 \\
\hline Gestation age* & 12 (IQR 11-12) & $0.99(0.77-1.27)$ & .946 & & \\
\hline $\begin{array}{l}\text { Gravidity* } \\
\text { Residence }\end{array}$ & \multicolumn{3}{|c|}{ Residence } & $0.74(0.28-1.96)$ & .548 \\
\hline Rural (160) & $4(2.5 \%)$ & 1 & & & \\
\hline Urban (100) & $2(2 \%)$ & $0.79(0.14-4.42)$ & .794 & & \\
\hline \multicolumn{6}{|l|}{ Education } \\
\hline No formal/primary (147) & $3(2.04 \%)$ & 1 & & & \\
\hline Secondary (86) & $2(2.3 \%)$ & $1.14(0.18-6.97)$ & .885 & & \\
\hline Tertiary (27) & $1(2.3 \%)$ & $1.84(0.18-18.43)$ & .602 & & \\
\hline \multicolumn{6}{|l|}{ Occupation } \\
\hline Housewife (1 14) & $4(3.5 \%)$ & 1 & & & \\
\hline Peasant (58) & $1(1.74 \%)$ & $0.48(0.052-4.41)$ & .519 & & \\
\hline Employed (88) & $1(1.14 \%)$ & $0.31(0.034-2.87)$ & .307 & & \\
\hline \multicolumn{6}{|l|}{ Marital status } \\
\hline Single (38) & $1(2.6 \%)$ & 1 & & & \\
\hline Married (222) & $5(2.2 \%)$ & $0.85(0.96-7.5)$ & .886 & & \\
\hline \multicolumn{6}{|l|}{ Previous miscarriage } \\
\hline No (221) & $5(2.3 \%)$ & 1 & & & \\
\hline Yes (39) & $1(2.5 \%)$ & $1.13(0.12-10)$ & .908 & & \\
\hline \multicolumn{6}{|l|}{ History of stillbirth } \\
\hline No $(225)$ & $5(2.2 \%)$ & 1 & & & \\
\hline Yes (35) & $1(2.9 \%)$ & $1.29(0.14-11.41)$ & .816 & & \\
\hline \multicolumn{6}{|l|}{ Keeping a cat } \\
\hline No $(170)$ & $1(0.5 \%)$ & 1 & & & \\
\hline Yes (90) & $5(5.7 \%)$ & $9.94(1.14-86.44)$ & .037 & $11.8(1.32-105.04)$ & .027 \\
\hline \multicolumn{6}{|l|}{ Unboiled water } \\
\hline Yes (91) & $3(3.3 \%)$ & 1 & & & \\
\hline No (169) & $3(1.8 \%)$ & $1.88(0.37-9.54)$ & .443 & & \\
\hline \multicolumn{6}{|l|}{ Chicken } \\
\hline Yes (176) & $2(1.14 \%)$ & 1 & & & \\
\hline No (84) & $4(4.8 \%)$ & $4.54(0.31-10)$ & .093 & & \\
\hline \multicolumn{6}{|l|}{ Mutton } \\
\hline Yes (118) & $2(1.7 \%)$ & 1 & & & \\
\hline No (142) & $4(2.8 \%)$ & $4.54(0.30-10)$ & .553 & & \\
\hline \multicolumn{6}{|l|}{ Pork } \\
\hline Yes (60) & $1(1.7 \%)$ & 1 & & & \\
\hline No (200) & $5(2.5 \%)$ & $1.52(0.17-14)$ & .708 & & \\
\hline \multicolumn{6}{|l|}{ Lamb } \\
\hline Yes (45) & $1(2.2 \%)$ & 1 & & & \\
\hline No (215) & $5(2.3 \%)$ & $1.05(0.11-10)$ & .967 & & \\
\hline $\begin{array}{l}\text { Beef } \\
\text { Yes (215) }\end{array}$ & $2(0.93 \%)$ & & & & \\
\hline No (45) & $4(8.89 \%)$ & $10.4(1.8-58.8)$ & .008 & & \\
\hline
\end{tabular}


FIGURE 2. (A) Hematoxylin and Eosin Stain (10x), Neutrophils Infiltrates Signifying Acute Inflammation. (B) Hematoxylin and Eosin Stain (20x), Lymphocytes and Plasma Cells Signifying Chronic Inflammation.

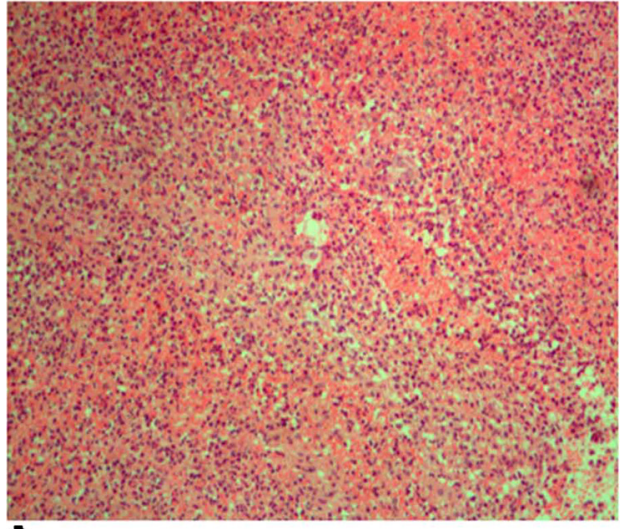

A

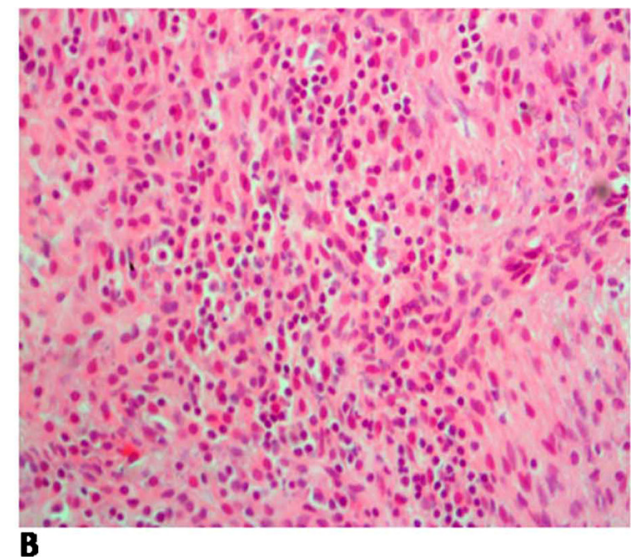

B
FIGURE 3. (A) Hematoxylin and Eosin Stain (20x), Black Arrows Showing Calcification. (B) Hematoxylin and Eosin Stain (10x) Brown Arrows Showing Areas of Necrosis with Neutrophils on the Background.

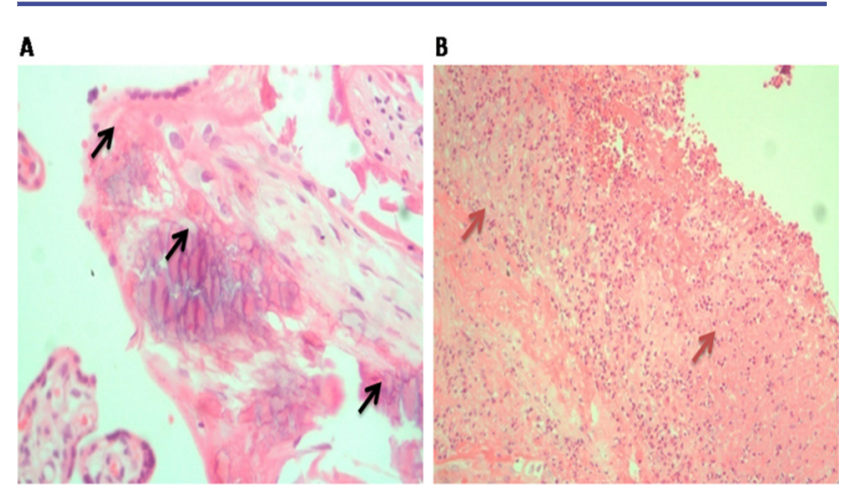

they can be easily overlooked in routine tissue studies. In addition, tissue necrosis and calcification have been found to be associated with IgG seropositivity in the current study, which is in agreement with a previous report. ${ }^{42}$ As a matter of fact, calcification and necrosis have been found to be common manifestations of toxoplasmosis. ${ }^{43}$ Generally, a positive association between IgG seropositivity and pathological changes, as observed in this study, suggests that T. gondii infection might have played an important role in spontaneous abortion in our setting. Further studies on the mechanisms through which T. gondii infection causes abortion are needed to provide a clearer understanding.
TABLE 4. Histopathological Changes and lgG Seropositivity Among 171 Women With Spontaneous Abortion

\begin{tabular}{|c|c|c|c|}
\hline Characteristics (n) & $\begin{array}{c}\lg G \\
\text { Seropositivity }\end{array}$ & OR $(95 \% \mathrm{Cl})$ & P-Value \\
\hline \multicolumn{4}{|l|}{ Inflammation } \\
\hline Absent (103) & 45 (43.7) & 1 & \\
\hline Present (68) & $41(60.3)$ & $1.95(1.05-3.64)$ & .035 \\
\hline \multicolumn{4}{|l|}{ Calcification } \\
\hline Absent (155) & $74(47.8)$ & 1 & \\
\hline Present (16) & $12(75.0)$ & $3.28(1.01-10.63)$ & .047 \\
\hline \multicolumn{4}{|l|}{ Necrosis } \\
\hline Absent (126) & $55(43.7)$ & 1 & \\
\hline Present (45) & $31(68.9)$ & $2.86(1.39-5.89)$ & .004 \\
\hline \multicolumn{4}{|l|}{ Macrophages } \\
\hline Absent (137) & $64(46.7)$ & 1 & \\
\hline Present (34) & $22(64.7)$ & $2.09(0.95-4.56)$ & .064 \\
\hline \multicolumn{4}{|l|}{ Lymphocyte } \\
\hline Absent (109) & $47(43.1)$ & 1 & \\
\hline Present (62) & $39(63.0)$ & $2.24(1.17-4.24)$ & .014 \\
\hline
\end{tabular}


TABLE 5. Median Titres in Relation to Histopathological Changes Among 171 Women With Spontaneous Abortion

\begin{tabular}{|c|c|c|c|}
\hline Characteristics (n) & $\begin{array}{l}\text { Median } \\
\text { IgG Titres } \\
(\mathrm{IU} / \mathrm{mL})\end{array}$ & IQR & P-Value \\
\hline \multicolumn{4}{|l|}{ Inflammation } \\
\hline Absent (45) & 47.85 & $30.00-99.53$ & \\
\hline Present (41) & 75.93 & $30.00-202$ & .252 \\
\hline \multicolumn{4}{|l|}{ Calcification } \\
\hline Absent (74) & 54.22 & 27.19-154.38 & \\
\hline Present (12) & 76.50 & $38.50-176.68$ & .278 \\
\hline \multicolumn{4}{|l|}{ Necrosis } \\
\hline Absent (55) & 52.22 & $30.00-118$ & \\
\hline Present (31) & 75.93 & $27.19-253$ & .244 \\
\hline \multicolumn{4}{|l|}{ Macrophages } \\
\hline Absent (64) & 54.22 & $30.54-118.18$ & \\
\hline Present (22) & 57.66 & $27.00-202.86$ & .922 \\
\hline \multicolumn{4}{|l|}{ Lymphocyte } \\
\hline Absent (47) & 52.22 & $30.00-99.77$ & \\
\hline Present (39) & 75.93 & $30.00-202.86$ & .312 \\
\hline
\end{tabular}

\section{Limitations}

The major limitations of this study were the failure to perform IgG avidity. Furthermore, sensitive techniques like polymerase chain reaction and immunofluorescent techniques for antigen detection could provide more information on the existence of parasite DNA in placental tissues.

\section{CONCLUSION AND RECOMMENDATIONS}

The seropositivity of specific T. gondii IgG antibodies among women with spontaneous abortion and placental histopathological changes is alarmingly high in our setting, with a significant proportion of women at risk of contracting primary infection. The high prevalence of toxoplasmosis in women keeping cats, as one of the T. gondii IgM predictors, suggests that more education should be provided to these women on the risk of contracting $T$. gondii infection, especially during pregnancy. Ideally, these women should be excluded in activities that expose them to contact with infected cats or cat faeces, such as feeding cats and gardening. This study has provided baseline information on the association between T. gondii infection and spontaneous abortion in a particular setting. As toxoplasmosis is one of the TORCH infectionstoxoplasmosis, other (syphilis, varicella-zoster, parvovirus B 19), rubella, cytomegalovirus, and herpes infectionsimplicated in causing poor pregnancy outcomes, these findings may contribute to the improvement of antenatal care services and may trigger policy makers into considering screening and treatment for the women found with a T. gondii infection during antenatal visits. In addition, our results emphasize the need to consider $T$. gondii infection as one of the possible causes of spontaneous abortion. Overall, a better understanding of the infection and its outcome, and the implementation of the measures mentioned above may have a dramatic impact on the reduction of the adverse pregnancy outcomes associated with $T$. gondii infection.

Acknowledgements: The authors would like to acknowledge the technical support provided by Mr. Vitus Silago and Mrs. Caroline Minja. Sincere gratitude to all staff at the Bugando Medical Centre, Sekou Toure regional hospital, Nyamagana district hospital, Buzuruga health centre, and Kamanga hospital. This study was supported by a research grant from CUHAS and BMC.

\section{REFERENCES}

1. Galván Ramírez ML, Valdez Alvarado V, Vargas Gutierrez G, Jiménez González O, García Cosio C, Vielma Sandoval M. Prevalence of lgG and IgM anti-Toxoplasma antibodies in patients with HIV and acquired immunodeficiency syndrome (AIDS). Rev Soc Bras Med Trop. 1997;30(6):465-467. CrossRef. Medline

2. Boto de los Bueis A, Vega Alemán D, Gálvez Acebal J, Merino Muñoz D, Creagh Cerquera R, Pujol de la Llave E. [Prevalence of latent toxoplasma infection in HIV infection patients]. An Med Interna. 1998;15(6):298-300.

3. Wanachiwanawin D, Sutthent R, Chokephaibulkit K, Mahakittikun V, Ongrotchanakun J, Monkong N. Toxoplasma gondii antibodies in HIV and non-HIV infected Thai pregnant women. Asian Pac J Allergy Immunol. 2001 ; 19(4):291-293. Medline

4. Falusi O, French AL, Seaberg EC, et al. Prevalence and predictors of Toxoplasma seropositivity in women with and at risk for human immunodeficiency virus infection. Clin Infect Dis. 2002;35(11):1414-1417. CrossRef. Medline

5. Skariah S, Mclntyre MK, Mordue DG. Toxoplasma gondii: determinants of tachyzoite to bradyzoite conversion. Parasitol Res. 2010;107(2):253-260. CrossRef. Medline

6. Elmore SA, Jones JL, Conrad PA, Patton S, Lindsay DS, Dubey JP. Toxoplasma gondii: epidemiology, feline clinical aspects, and prevention. Trends Parasitol. 2010;26(4):190-196. CrossRef. Medline

7. Jones JL, Kruszon-Moran D, Wilson M, McQuillan G, Navin T, McAuley JB. Toxoplasma gondii infection in the United States: seroprevalence and risk factors. Am J Epidemiol. 2001;154(4):357-365. CrossRef. Medline

8. Boyer KM, Holfels E, Roizen N, et al; the Toxoplasmosis Study Group. Risk factors for Toxoplasma gondii infection in mothers of infants with congenital toxoplasmosis: implications for prenatal management and screening. Am J Obstet Gynecol. 2005;192(2):564-571. CrossRef. Medline

9. Kravetz JD, Federman DG. Prevention of toxoplasmosis in pregnancy: knowledge of risk factors. Infect Dis Obstet Gynecol. 2005;13(3):161-165. CrossRef. Medline

10. Flatt A, Shetty N. Seroprevalence and risk factors for toxoplasmosis among antenatal women in London: a re-examination of risk in an ethnically diverse population. Eur J Public Health. 2013;23(4):648-652. CrossRef. Medline 
11. Linguissi LSG, Nagalo BM, Bisseye C, et al. Seroprevalence of toxoplasmosis and rubella in pregnant women attending antenatal private clinic at Ouagadougou, Burkina Faso. Asian Pac J Trop Med. 2012;5(10):810-813. CrossRef

12. Ryan KJ, ed. Sherris Medical Microbiology: An Introduction to Infectious Diseases. 3rd ed. East Norwalk, Connecticut, USA: Appleton \& Lange; 1994.

13. Stegmann BJ, Carey JC. TORCH infections. toxoplasmosis, other (syphilis, varicella-zoster, parvovirus B19), rubella, cytomegalovirus (CMV), and herpes infections. Curr Womens Health Rep. 2002;2(4):253-258. Medline

14. Tenter AM, Heckeroth AR, Weiss LM. Toxoplasma gondii: from animals to humans. Int J Parasitol. 2000;30(12-13):1217-1258. CrossRef. Medline

15. Dubey JP, Jones JL. Toxoplasma gondii infection in humans and animals in the United States. Int J Parasitol. 2008;38(1 1):1257-1278. CrossRef. Medline

16. Goldstein EJC, Montoya JG, Remington JS. Management of Toxoplasma gondii infection during pregnancy. Clin Infect Dis. 2008;47(4):554-566. CrossRef. Medline

17. Al Hamdani MM, Mahdi NK. Toxoplasmosis among women with habitual abortion. Le Revue de Santé de la Méditerranée Orientale. 1997;3(2):310-315.

18. Dunn D, Wallon M, Peyron F, Petersen E, Peckham C, Gilbert R. Mother-to-child transmission of toxoplasmosis: risk estimates for clinical counselling. Lancet. 1999;353(9167): 1829-1833. CrossRef. Medline

19. Chen KT, Eskild A, Bresnahan M, Stray-Pedersen B, Sher A, Jenum PA. Previous maternal infection with Toxoplasma gondii and the risk of fetal death. Am J Obstet Gynecol. 2005;193(2):443-449. CrossRef. Medline

20. Mwambe B, Mshana SE, Kidenya BR, et al. Sero-prevalence and factors associated with Toxoplasma gondii infection among pregnant women attending antenatal care in Mwanza, Tanzania. Parasit Vectors. 2013;6:222. CrossRef. Medline

21. Doerhing E, Reiter-Owona I, Bauer O, et al. Toxoplasma gondii antibodies in pregnant women and their newborns in Dar es Salaam, Tanzania. Am J Trop Med Hyg. 1995;52(6):546-548. CrossRef. Medline

22. Shao ER, Ndazana SG, Chacha W, et al. Sero-prevalence and factors associated with Toxoplasma gondii infection among pregnant women attending antenatal care in the referral hospital in Tanzania: cross sectional study. Ann Clin Lab Res. 2015;3(2):17. CrossRef

23. Mirambo MM, Kivambe C, Mushi MF, et al. High seropositivity of specific Toxoplasma gondii IgG antibodies among HIV/AIDS patients with immunological failure attending a tertiary hospital in northwestern Tanzania. Tanzan $J$ Health Res. $2015 ; 18(1)$

24. Tammam AE, Haridy MA, Abdellah AH, Ahmed SR, Fayed HM, Alsammani MA. Seroepidemiology of Toxoplasma gondii infection in women with first trimester spontaneous miscarriage in Qena governorate, Egypt. J Clin Diagn Res. 2013;7(12):2870-2873. Medline

25. Vado-Solís IA, Suárez-Solís V, Jiménez-Delgadillo B, Zavala-Velázquez JE, Segura-Correa JC. Toxoplasma gondii presence in women with spontaneous abortion in Yucatan, Mexico. J Parasitol. 2013;99(2):383-385. CrossRef. Medline

26. Kish L. Survey Sampling. New York: John Wiley \& Sons; 1965

27. Kistiah K, Barragan A, Winiecka-Krusnell J, Karstaedt A, Frean J. Seropositivity of Toxoplasma gondii infection in HIV-positive and HIV-negative subjects in Gauteng, South Africa: Festschrift. South Afr J Epidemiol Infect. 2011;26(4):225228.

28. Fischer AH, Jacobson KA, Rose J, Zeller R. Hematoxylin and eosin staining of tissue and cell sections. CSH Protoc. 2008;2008:pdb.prot4986. Medline

29. Almishhadani J, Aljanabi A. Toxoplasmosis and cytomegalovirus infection among aborted women in Al-Anbar Governorate. Al-Anbar Med J. 2008;6:88-97.
30. Elhag BKE, Elturabi SEM. Seropositivity of toxoplasmosis among women with abortion in Khartoum State. Journal of Coastal Life Medicine. 2015;3(7):551-554. CrossRef

31. Ghasemi FS, Rasti S, Piroozmand A, et al. Toxoplasmosis-associated abortion and stillbirth in Tehran, Iran. J Matern Fetal Neonatal Med. 2016;29(2):248-251. CrossRef. Medline

32. Ferguson DJP. Toxoplasma gondii: 1908-2008, homage to Nicolle, Manceaux and Splendore. Mem Inst Oswaldo Cruz. 2009;104(2):133-148. CrossRef. Medline

33. Ling LY, Nissapatorn V, Sawangjaroen N, Suwanrath C, Chandeying V. Toxoplasmosis-serological evidence and associated risk factors among pregnant women in southern Thailand. Am J Trop Med Hyg. 2011;85(2):243-247. CrossRef. Medline

34. Sahwi SY, Zaki MS, Haiba NY, Elsaid OK, Anwar MY, AbdRabbo SA. Toxoplasmosis as a cause of repeated abortion. J Obstet Gynaecol. 1995;21(2):145-1 48. CrossRef

35. Elhag BKE, Elturabi SEM. Seroprevalence of toxoplasmosis among women with abortion in Khartoum State. Journal of Coastal Life Medicine. 2015;3(7):551-554. CrossRef

36. Emelia O, Rahana AR, Mohamad Firdaus A, et al. lgG avidity assay: a tool for excluding acute toxoplasmosis in prolonged lg $M$ titer sera from pregnant women. Trop Biomed. 2014;31(4):633-640. Medline

37. Zhang YP, Song RH. [Investigation on pregnancy outcomes and risk factors in pregnant women infected with Toxoplasma gondii]. Zhongguo Xue Xi Chong Bing Fang Zhi Za Zhi. 2014;26(2):221-223.

38. Castaño $P$, Fuertes $M$, Ferre I, et al. Placental thrombosis in acute phase abortions during experimental Toxoplasma gondii infection in sheep. Vet Res. 2014;45(1):9. CrossRef. Medline

39. Castro ECdC. Salge AKM, Galdino FJB, Ferraz MLF, Reis MAd, Corrêa RRM, Teixeira VdPA. Placental villitis and its relationship with fetal and maternal outcome. Rev Bras Ginecol Obstet. 2004;26(10):807-812.

40. Benirschke K, Coen R, Patterson B, Key T. Villitis of known origin: varicella and toxoplasma. Placenta. 1999;20(5-6):395-399. CrossRef. Medline

41. Redline RW. Villitis of unknown etiology: noninfectious chronic villitis in the placenta. Hum Pathol. 2007;38(10):1439-1446. CrossRef. Medline

42. Gutierrez Y. Diagnostic Pathology of Parasitic Infections with Clinical Correlations. 2nd ed. New York: Oxford University Press; 2000.

43. Lee GT, Antelo F, Mlikotic AA. Cerebral toxoplasmosis. Radiographics. 2009;29(4):1200-1205. CrossRef. Medline

\section{Peer Reviewed}

Competing Interests: None declared.

Received: 14 Dec 2016; Accepted: 25 Jul 2017

Cite this article as: Machumi I, Mirambo MM, Ruganuza D, Rambau P, Massinde AN, Kihunrwa $A$, et al. Factors Associated With Toxoplasma gondii $\lg G$ and $\lg M$ Antibodies, and Placental Histopathological Changes Among Women With Spontaneous Abortion in Mwanza City, Tanzania. East African Health Res J. 2017;1(2):86-94. https://doi.org/10.24248/EAHRJ-D-16-00408

(c) Machumi et al. This is an open-access article distributed under the terms of the Creative Commons Attribution License, which permits unrestricted use, distribution, and reproduction in any medium, provided the original author and source are properly cited. To view a copy of the license, visit http://creativecommons.org/licenses/by/ 3.0/. When linking to this article, please use the following permanent link: https:// doi.org/10.24248/EAHRJ-D-16-00408 